\title{
The Differend of Justice: Violence and Redemption in Dworkin's Justice for Hedgehogs
}

\begin{abstract}
This article uses Ronald Dworkin's argument for the unity of value to explore the redemptive core of modern legal order. Dworkin establishes a formal unity: all legal claims reside within a linked framework of moral justification. However, Jean-Francois Lyotard's concept of the differend exposes a lingering gap. Arguments within a moral universe do inevitably converge, but such unity is only possible due to the formative violence enacted by such orders. Dworkin hopes to provide the definitive statement against moral subjectivity, but in its purest form, he proves precisely the opposite. The lesson to draw from Dworkin's work is that 'justice' is ultimately only the means by which political orders categorize and thereby sustain their own formative acts of exclusion under the guise of offering their redemption.
\end{abstract}

KEYWORDS: justice, interpretation, moral reason, Dworkin, Lyotard, Gadamer

In Justice for Hedgehogs, the final major work of his long career, Ronald Dworkin recalls that that old line of poetry, made famous by Isaiah Berlin: 'the fox knows many things, but the hedgehog knows one big thing' (Berlin I953: 3). Dworkin's goal: nothing less than the integration of 'theories of truth, language, and metaphysics with and into the more familiar realms of value' (Dworkin 20II: 264). In this formulation, every seeming distinction between moral claims is facile, as are distinctions between objects of interpretation and the interpreting subject. The apparent contradictions are simply a product of thinking like a fox. Once framed correctly, the hedgehog's perspective will reveal a deeper unity and coherence.

This article takes Dworkin's argument as an invitation to explore the possibilities and limits of justice. Hedgehogs is important, I argue, not because it fully succeeds, but rather due to the nature of its failure. Dworkin does correctly describe an underlying unity of political, moral, and legal thought. However, this unity remains incomplete. And, crucially, its incompleteness cannot be detached from its scope. As Dworkin successfully proves, the trans-historical unity of value is not unique to his approach but instead is present in every instance and formulation of justice. His failures, therefore, expose the failures of justice as such.

But what exactly is the nature of this failure? Though he does not characterize it in these terms, I argue that Dworkin's 'unity' is best understood as a form of fidelity to the redemptive potential of shared meaning, which regards every form of exclusion as an invitation to recuperation. This orientation toward redemption is the beating 
heart of modernity's secular orientation - a world without theological certainty, where faith must be transferred to the architecture of justice (Schmitt 1985). But for all that 'justice as redemption' is ubiquitous, it is rarely acknowledged as such. And this clarifies the importance of Dworkin's work. By recentering our theoretical gaze on the process of justification, and by challenging any attempt to fragment our perspective, he provides a crucial vantage point for describing and critiquing the redemptive impulse.

The terms of this argument are presented in two stages. The first is a process of immanent critique, in which Dworkin's work is compared to the hermeneutics of Hans-Georg Gadamer. While these approaches are by no means identicalindeed, Dworkin's late career work might be read as a repudiation of his earlier dalliance with Gadamer-beneath the surface, they each embody a similar faith in the potential for integration. That is, they presume that interpretive gaps are not only amenable to negotiation, but that such negotiation is the heart of meaningful political engagement. The symmetry at this level may be most usefully understood as a shared commitment to the idea of interpretation as a technique of redemption, where justice is not defined by the elimination of exclusion but rather by the continuous practice of redeeming exclusions by fitting them into a larger scheme of justification. In Dworkin's case, this occurs through a process of persistent self-evaluation - which regards each supposed gap as an invitation to recalibrate the linked structure of normative obligation. Gadamer rejects this integrative objective-arguing for the need to preserve interpretive gaps as the necessary terrain on which understanding may be sought. These approaches differ in both goal and method, but converge in one crucial way: for each, justice is not a result to be achieved but rather a process of continual transition-conducted in the name of a redemptive principle that exceeds material achievement.

The second stage of the argument takes this immanent critique as an invitation to reflect on the limitations of justice as redemption as a form of political practice. Here, I draw on Jean-François Lyotard's concept of the differend to illustrate the durability of a formative violence, which includes both the conceptual exclusion of meaning-making as well as the material exclusion of law-making. The differend of justice is the inextinguishable violence that resides within the structures of every moral order-which can neither be acknowledged nor resolved. It is the point of exception, which cannot even be characterized as injustice, because it exceeds the concept of justice itself. Dworkin's own argument for the unity of moral thought provides the necessary bridge for this claim. Tracing the flows of normativity backward exposes the indelible status of redemption at the heart of every justice claim.

By stripping away all the accouterments of normativity, Dworkin hopes to restore its universal potential. All political claims, he argues, are ultimately normative in nature, and therefore imply the potential to stitch together that which appears fractured. By establishing the universality of this premise, Dworkin seeks to divide the world between justice and injustice. But in this separation the excluded third is never fully resolved. It lingers on, as the foundational violence upon which its order is sustained, and against which the redemptive potential of justice is delineated. Because it cannot be incorporated, such violence is neither 'just' nor 'unjust;' it simply is. 
Dworkin deserves credit and attention for scaling the heights of theoretical inquiry. He has climbed to the highest peak of justice. Unfortunately, it is only from this vantage point that its tensions are revealed to be terminally irresolvable.

\section{The Unity of Value: Interpretation for Hedgehogs}

Justice for Hedgehogs is framed as a reformulation of 'law as integrity', Dworkin's prior model of legal interpretation. That approach posited an active role for the legal thinker: to make law 'the best that it can be' (Dworkin I986: 53). In contrast with the 'plain facts' view of law that imagines a legal order to exist in an objective sense (See Hart I994), Dworkin argues that interpretation is a constructive practice that necessarily helps to generate the concept being interpreted. Given these constraints, any decision about what the law is must also be a decision about what the law ought to mean. But, simultaneously, the normative value of law cannot be disentangled from its historical location. That is: what the law ought to be depends on its interpretive community (Dworkin I986: 45-86). A judge should interpret legal practices in the best light, but this is always dependent on existent communal interpretive practices that render the concept meaningful.

In Justice for Hedgehogs, Dworkin criticizes this old approach. Law as integrity, he now argues, suffered from a critical lacuna. As a theory of legal interpretation, it could instruct a judge how to act with integrity but it lacked the scope needed to justify why a judge should adopt this method in the first place. In effect, its interpretive mode required an act of faith in the principle that law deserves to be treated with integrity. This means its entire apparatus was parasitic on a prior, external choice to affirm a 'larger integrated network of political value' that enframes the entire structure of legal reason (Dworkin 20I I: 405; see also Přibán̆ 2006: 462-65). Law as integrity, in this way, smuggled the notion of fidelity to law into the process of interpreting it.

The realization that law as integrity presumed a truth it lacked the capacity to justify leads him to broaden his perspective. In doing so, he concludes that all interpretation follows this same structure-any moral statement necessarily contains an implicit self-affirming principle that statements can in fact be valid (Dworkin 20II: 7). Furthermore, this principle extends to 'nonmoral' statements as well. After all, stating the absence of an obligation is simply a reconfigured moral judgment, insofar as it asserts the truth of nonobligation (Dworkin 20II: 40-45). This insight is similar to Nietzsche's that even the most absolute critique of morality remains grounded in a will to truth, which is not the remainder of an ideal but is 'this ideal itself in its strictest, most spiritual formulation, esoteric through and through, with all external additions abolished, and thus not so much its remnant as its kernel' (Nietzsche I967: I60). However, while Nietzsche sees this as reason to doubt the practice of truth itself, Dworkin interprets this as a call to reaffirm truth's unity. In his view, even the most profound relativism retains a standpoint from which the impossibility of judgment can be articulated. Thus, the arguments of positivists, deconstructionists, and all those in between suffer from the same basic flaw: they rely on an external form of skepticism that looks beyond itself for justification, seeking an Archimedean point from which one may judge 
morality from outside morality (Dworkin 20II: $3 \mathrm{I}$ ). But since such a point cannot exist, any justification must come from within.

Therefore, Dworkin argues, moral judgment must be regarded as a single, unified set of interpretive obligations. There are no objective, bare truths in moral justification; there are only reasons. If a claim is true, it is only because a reason makes it so. The resulting system of reasons is defined by interpretive consistency: moral claims are true when they fit together with other moral claims and false when they cannot be incorporated into the fabric of a moral universe. There is no standpoint from which to evaluate truth outside these moral claims. It is, as the saying goes, turtles all the way down. Moreover, since external resolution is impossible, 'the argument ends when it meets itself, if it ever does' (Dworkin 20I I: I I7).

This does not, however, mean that truth is simply up for grabs. After all, 'morality is in the eye of the beholder' is a self-refuting claim, since it relies on a will to truth that exceeds the scope of its argument. Durable disagreement over the nature of morality is inevitable, but this does not disprove the unity of value; it merely reveals the need for further interpretive refinement (Dworkin 20I I: 5I). All claims are moral, but the only truthful moral claims are those that affirm the possibility of a shared interpretive obligation. If this is correct, then the essential moral object is not truth itself, but instead is a fidelity to the search for truth, and the unifying structure of moral reason is the principle of responsibility and mutual respect (Dworkin 20II: II2).

\section{The Role of History: Fidelity or Transcendence?}

Dworkin believes that the hedgehog's approach, which treats law as merely 'a branch, a subdivision, of political morality' provides a unified picture of the world (Dworkin 20II: 406). The seed of this idea was present in his earlier formulation of law as integrity, but that seed could only reach its potential once detached from the confines in which it had been formulated. It is worth dwelling for a moment on precisely what is sacrificed in this move.

Law as integrity was defined by the productive tension between two distinct interpretive responsibilities: 'best light' and 'fit'. To interpret a law in the best light is to attach it to a larger process of moral judgment. By contrast, 'fit' means that judges are tasked with seeing a thing as the best version of that thing and not some other thing. This requirement of fit signifies that 'the history or shape of a practice or object constrains the available interpretations' (Dworkin I986: 52). Here, it is worth noting that Dworkin approvingly cites Gadamer, 'whose account of interpretation as recognizing, while struggling against, the constraints of history strikes the right note' (Dworkin I986: 62).

\section{The Progressive Case against Tradition}

In Justice for Hedgehogs, Dworkin splits apart the relationship of fit and best light. Now, the best version of law is simply the one that expresses its value in a unified fashion. The frame of reference is one's own moral universe, which should include fidelity to the object of inquiry, but which always conceives of that fidelity as 
conceptually contained within to the larger demand for unity. Accordingly, while a historical perspective will often be crucial to grasping the contours of moral truth, there is no obligation to honor such history beyond the value contained in the content of its moral claims. To do otherwise would trap the moral structure of reason within the amber of a particular historical tradition (Dworkin, 20II: 66, 3I9, 4I5). The danger here is particularly acute in the case of extreme evils located in a collective past. Why treat decisions such as Dred Scott or Korematsu with integrity? They are historical facts, but facts whose validity should be actively written out of existence (See Donato I988; Fleming 1997). Indeed, for Drucilla Cornell and Nick Friedman (2010), Dworkin's new approach is laudable precisely because he now treats history as merely one moral object among others. By rejecting 'the precedence of the past over both the present and the future' he returns judgment to its proper location: a progressive present tense (Cornell and Friedman 20I0: 24).

Habermas (I990) clarifies the significance of this move, arguing that the inherent imbalances within history necessarily structure interpretation. As such, hermeneutics is subject 'to the repressivity of forces which deform the intersubjectivity of agreement as such and which systematically distort everyday communication. It is for this reason that every consensus, as the outcome of an understanding of meaning, is, in principle, suspect of having been enforced through pseudo-communication' (Habermas I990: 267). Hermeneutic engagement requires good faith from all parties, but history can never play such a role. Its deformities, therefore, will be incorporated into the present without challenge, thus 'nullifying or rendering absurd our emancipatory aspirations' (How I995: I43). In this way, the unbridgeable prejudices of the past are built into the hermeneutic relationship by the simple act of taking them as legitimate.

According to the progressive argument, Dworkin was correct to dispense with his Gadamerian inclinations. The hermeneutic perspective is a useful model for approaching interpretive engagement, but fidelity to the text is a means for pursuing truth, not an independent value. By the same light, tradition is valuable only insofar as a unified conception of value gives us good reason to regard it as such. Past wrongs are not to be respected simply because they are part of a continuing order, but instead should be excised to help sustain a genuinely unified moral order. The ideal act of interpretation draws the external object out of its original time and place to make it present. It expresses the ever-evolving truth of an omnipresent now, in which the past is never truly past but instead is renewed by the constant obligation of justification.

\section{Gadamer and Dworkin's Lost Horizons}

To Dworkin, this move away from Gadamerian hermeneutics is necessary. It is worth considering, however, whether the opposite move might have been superior. After all, Gadamer would likely argue that Dworkin's recuperative attitude toward truth is the real problem. The unity of value implies that every dissonance may ultimately be expressed through incorporation; the appearance of the gap disappears in the expression of underlying truth. But what if the presence of difference is the very condition of thought? 
For Gadamer, understanding is not something possessed by subjective agents but instead is implicit in the structure of conversation itself (Gadamer 2004: 293). Truth, to the extent that it is possible, is constituted by the space between a subject and a text; it is not something discovered or articulated by the subject. In this process, the enduring friction generated by the discontinuity between worlds is the necessary precondition for understanding. The Enlightenment has taught us to treat prejudice as an unadulterated negative, as the bane of objectivity and the prioritization of self-interest over justice. But this is itself a (specifically modern) prejudice: paradoxically, a prejudice against prejudice (Gadamer 2004: 277). The flaw of this approach is its desire to generate knowledge, as opposed to understanding - and thereby to achieve control rather than engagement (Gadamer 2004: xxxii). Knowledge takes place within the boundaries of a horizon; it depends on the preformed network of concepts and effective history. The place of a subject in a particular moment provides her with a broad but finite horizon of potential understanding. Understanding, by contrast, shifts horizons. By engaging with a perspective outside of an effective history, one's own perspective must also shift. Understanding only emerges when horizons overlap, provoke conflict, fuse. It requires openness as well as tension.

Thus, what Dworkin diagnoses as holes in a unified order-the unfilled spaces between reasons and their justification, between subject and object, between past and present-Gadamer treats as necessary. A world without gaps would need no bridges and thus would produce no understanding (Gadamer 2004: xxviii). Indeed, understanding is nothing but the temporary bridges built across these gaps. Rather than seeking to fill these holes, we should regard the lingering dislocation they produce as essential to meaning-making.

By this argument, we might characterize Justice for Hedgehogs as terminally misguided. Faced with the inherent doubt that comes from fusing horizons-its imperfection and incompleteness-Dworkin shies away. He perceives this insecurity as dangerous, and therefore seeks to quash it under the weight of moral unity. But this task is ultimately fruitless. He will inevitably reach, as Wittgenstein might say, a bedrock where his spade is turned and whatever justification may be supplied beyond this point is simply 'a kind of ornamental coping that supports nothing' (Wittgenstein I968: \$2I7). And there, faced with the seeming nihilism at the heart of interpretation, he 'would rather will nothingness than not will' (Nietzsche 1967: 97).

From the hermeneutical perspective, then, Dworkin's choice to double down on the principle of unity is a colonizing act, an attempt to compel coherence and meaning. This effort can only produce a false form of closure, in which the interpreter claims to discover truth that she herself has in fact created. In the name of truth, the hedgehog eliminates the possibility of understanding.

\section{Interpretation as Redemption: The Formal Unity of Interpretive Approaches}

The debate described in the previous section-progressive unity versus hermeneutic disjuncture-is organized primarily around a presumed break between Dworkin's 
old and new approaches. Where he once aligned with the Gadamerian model of effective history and thereby sided (at least partially) with the foxes, he has now chosen the logic of the hedgehog. Framed in this way, the key question raised by Justice for Hedgehogs is simply whether this choice is justified. Was Dworkin right to reduce the force of history, to side with the progressive model of free-floating reason?

However, the caesura between these perspectives is smaller than it seems. While different in some respects, these approaches might best be understood as a parallax effect: the result of looking at the same phenomenon of judgment from different vantage points. Ultimately, each of these interpretive approaches is founded on a redemptive narrative, which treats the persistent fact of difference as an opportunity for the recuperation of order.

The meaning of this process may be characterized in an almost limitless variety of ways-with fidelity to an interpretive past or to a timeless morality being merely a small subset of the possibilities. But in any case, the one thing justice cannot mean is the straightforward admission of unjustifiable violence at the heart of political unity. Such violence is the theological remainder, the necessary byproduct of endless and irresolvable debates over interpretation (Schmitt 2003). We are asked to justify, but all justification occurs only against the background of debts that may never be repaid, owed to those whose very existence was nullified to establish the specific, material present within which such debates take place. The full ramifications of this effect are explored below in section IV. First, however, the convergence of these seemingly distinct approaches must be mapped.

\section{The Redemptive Core of Law as Integrity}

To define the structure of this redemptive impulse, it is helpful to start with Dworkin, and the supposed shift from law as integrity to the unity of value. What we find is far more similarity than difference in these approaches. Indeed, every significant element of the argument from Justice for Hedgehogs is prefigured in the earlier work.

For the early Dworkin, the commitment to the past as a distinct obligation is real, but is nevertheless framed as a mechanism for stabilizing the present coherence of moral reason (Hutchinson I987). Judgment means regarding the mistakes of the past as negated principles. We honor the story of the law through its progressive reconstitution: binding together past and present by conceiving of mistakes as amenable to rectification through the law-rather than through revolution. This teleology of progress provides a mechanism for affirming the principles of a moral order against its historical failures (Meister 20II: 85-86). The contiguous principles that unify a constitutional history come to life precisely through their progressive incorporation into the present.

Understood this way, the obligation of fit was never a genuine commitment to the externality of history, but rather was an internal obligation of reason. Its emphasis on unity always required incorporation of the past into the present; the river could only flow in one direction. The priority of moral coherence is absolute, while the obligation to an imagined past endlessly recedes. 
Therefore, Justice for Hedgehogs merely states clearly what was already implicit: both integrity and the unity of value stem from the impulse to read the positive values of a moral order against its failures, to redeem the system by situating its core principles against those past injustices. Doing so honors the continuity of community while redeeming what we now take to have been erroneous (See Balkin 2OII). To speak of justice, in either case, is to affirm a basic shared human dignity, which shows that no one is irredeemable.

Dworkin's interpretive method was never in need of rescue from a conservative reliance on tradition over present judgment; rather, it needed a philosophical justification for why the present is permitted to colonize its subject. Justice for Hedgehogs provides that justification, by treating it not as colonization but instead as redemption.

\section{The Redemptive Core of Gadamer's Hermeneutics}

What then of Gadamer? Does he not provide an alternative approach, one untainted by such universalizing structures? If law as integrity is a failed hermeneutics, one implicitly guided by the hedgehog's impulse, why paint Gadamer with the same brush? After all, his approach is built around active resistance to the incorporative techniques of enlightenment thought, which collapse the incommensurable gap between past and present into a unifying logic of reason (Gadamer: 273-74).

However, as Jacques Derrida argues, the very attempt to theorize this gap itself imposes a form of unity. Even as Gadamer attempts to evade the logic of rationality, his interpretive procedures necessarily reimpose a will to meaning. This is because 'we can pronounce no single destructive proposition which has not already had to slip into the form, the logic, and the implicit postulations of precisely what it seeks to contest' (Derrida I978: 280-8I). The very act of interpretation involves the generation of order.

In particular Derrida focuses on the concept of 'good will', which, for Gadamer, is the necessary condition for successful interpretation. It does not insist on the construction of a single truth but rather seeks the understanding that is possible among truths. This permits consensus without agreement (Gadamer I989: 55). This notion of good will, however, is ill-equipped for the hidden traps and closures that Derrida sees as intrinsic to communication. Even more, good will is infeasible in the context of an unreliable interlocutor. For good will to produce understanding, both the subject and object of interpretation must remain open to the other (Gadamer 2004: 355). But this cannot account for objects of inquiry that actively seek to block shared meaning. For example, this is a problem in psychoanalysis, where 'the aim is to understand, not what the other wants to be understood, but exactly that which the patient wishes to conceal' (Shapcott 200I: I9I).

Once again, the fact of historical wrongs clarifies this problem. When interpreting the law, one must constantly struggle with a legal history replete with grave exclusions. The Gadamerian interpreter, facing such a reality, is forced to search for a foothold of good faith-a way in which the exclusion may be understood without being affirmed. This is not likely to be framed as a project of 'justice', but 
the resemblance is uncanny. Just as with Dworkin, the desire to understand the legal order implicitly contains an expression of faith in the potential good will of its structure. One must be willing to read its failures as horizons not yet fused or else abandon the prospect of interpretation as such. This faith, as with Dworkin, enacts a narrative of continuity.

Moreover, the manner in which horizons may be fused depends on a hidden form of exclusion, stemming from the necessity for mutuality. While engagement may shift horizons, it can only occur if both sides are willing to put themselves at risk. This means that the 'hermeneutic experience extends as far as does reasonable beings' openness to dialogue' (Gadamer 2004: 570, emphasis added). While he intends this to clarify the essentially limitless scope of dialogue, it is crucial to note how casually Gadamer slips into the language of reasonableness. Indeed, as framed here it is quite difficult to distinguish meaningfully his theoretical structure from that of Rawlsian political liberalism. Both require the posited framework of the reasonable-defined as the willingness to converse on terms that that arise out of but do not impose any particular effective history (See Rawls 2005: 37-40). Gadamer fills this concept of reasonableness with less content than Rawls, to be sure, but this does not alter the basic formal similarity.

Therefore, Gadamer is no better equipped than the liberals to deal with the circularity of this concept. What distinguishes reasonable subjects (with whom understanding may be achieved) from enemies (who seek only destruction)? Only the judgment of reasonable subjects-who mark themselves as reasonable through their willingness to engage. The unreasonable other is thus conceptually essential -it clarifies the capacity for dialogue through its absence-but also necessarily excluded (See O'Neill I997, Schmitt 2003). The result is a form of stasis, in which such unreasonable outlaws linger in a sort of perpetual limbo and mark the undefined exteriority of hermeneutic engagement. In Derrida's terms, this reveals that the supposed 'continuity of rapport' at work in hermeneutic understanding is in fact built upon 'the interruption of rapport, a certain rapport of interruption' (Derrida I989: 53).

\section{Redemptive Unities: The Search for Truth}

Each of these interpretive models is struggling with the same problem: how to articulate a concept of fit that does not self-destruct under the weight of an interpretive unity. Because none can accomplish this goal, they default to redemptive stories, whereby the remaining gap between what is best and what is understood may be justified. In one form or another, that gap is treated as an invitation to justification. In this respect, they all construct theodicies, interpretive models meant not just to explain the fact of evil but also to incorporate that evil into a broader narrative of the good.

In a certain sense, therefore, Dworkin's argument in Justice for Hedgehogs is correct. He quite brilliantly demonstrates that there is no 'outside' to value; it encompasses the entire universe. Further, this universality of value is intrinsic to every interpretive effort. However much an approach might pay fealty to the notion of openness, that commitment is founded on the imposition of order. The 
hedgehog's justice is therefore neither more progressive nor more universal than any other approach: it merely expresses those features with greater clarity.

However, this is a hollow victory. Dworkin has revealed a universal structure, but in the process has lost hold of its meaning. As I explain in the next section, the redemptive impulse may inflect all moral claims, but in doing so it merely clarifies the impossible task of expunging the ghosts that haunt our political universe.

\section{The Differend of Justice: Violence beyond Redemption}

Dworkin convincingly argues for an infinite system of value-an unbounded universe of moral claims. However, this infinity remains sharply constrained. Within it, one may travel endlessly, but the journey only leads in a circle back to the same location. It is therefore a secular infinity, one without beginning or end, an eternal present. The different techniques of interpretation (law as integrity, the unity of value, Gadamerian hermeneutics, utilitarianism, positivism, the original position, etc.) each generates its own flavor of infinity, but all of these approaches share the same underlying problem, a variation of Russell's paradox: they seek to create a set of all things but cannot account for the system of thought necessary to generate such a set in the first place (Barrow 2005: 67-76, I66-68). In the case of the law, this obscures the lingering necessity of legal decision-something that can be justified $b y$, but never incorporated into, the unity of value.

This section seeks to clarify the extent of this limit. It does so by applying Lyotard's concept of the differend to the practice of moral reason. To explain: the differend is a lingering injury that falls outside the accepted terms of the language game in which it is manufactured. It cannot be addressed on the terms of a shared interpretive structure because it represents pain beyond articulation. It is like an untranslatable word, whose meaning is altered when expressed in a different language. To the extent that it can be filtered into a new language it loses an element of its own identity; it becomes a new, slightly different concept. For example, any attempt to litigate the Holocaust founders on the incapacity for legal concepts to capture the world-destroying nature of that act. To litigate the crime washes away its unique texture and renders it banal (Lyotard I988: 56-57). The well-meaning attempt to express fidelity to victims falters in the face of the ineffable reality of the act.

In making this argument, Lyotard treads on familiar ground. Like Dworkin and Gadamer, he also emphasizes the endlessly recursive process of understanding, the impossibility of stepping outside interpretation. For him this is expressed: 'To doubt that one phrases is still to phrase' (Lyotard I988: xi). Just as an argument against moral obligation is still a moral argument, to reject the representational capacity of language is still to make a representational claim. Any attempt to limit the scope of interpretation, therefore, is self-contradictory. The 'last phrase' ceases to be final as soon as it is named as such (Lyotard I988: II). As such, Lyotard shares the perception that judgment is limited to endless recirculation with no objective resolution.

The key difference is his attitude toward this limitation of reason. For Dworkin, the lack of external certainty proves the unity of value; if there can be no permanent 
foundations, all that is left is a secular world of linked justifications, a closed universe. But what if the question of externality is divorced from the question of foundations? Self-justifying grounding may be impossible, but this does not foreclose the possibility of a second type of external object: remainders. While foundations are positive externals-they provide the secure basis from which a moral claim may be advanced-remainders are negative exclusions. They exist in a space beyond reason and evade explanation or even comprehension (Badiou 20II: 94).

The defining feature of every concept of justice in our secular age is its attitude toward such remainders. In every case an attempt is made to formalize them, to comprehend them, to make them explicable. They cannot be erased in a material sense-violence and exclusion are indelible features of a world without God-but they can be neutralized. This entails fitting them into a conceptual scheme, sorting them, explicating them. As soon as one is capable of correctly formulating the act of violence, it ceases to be arbitrary; it is given meaning through its articulation.

Justice is therefore the practice by which distinctions are drawn between forms of exclusion. In the first case are those who suffer for no cause (victims). In the second case are those who inflict suffering without justification (perpetrators). The line is drawn in this fashion in order to generate legitimacy for a certain kind of violence: the punishment meted out by a collective will. The collectivization of judgments on violence is necessary to restrain victims from lashing out and thus becoming perpetrators of violence themselves (Meister 20II: 35; see also Locke 2008: 27276,350353 ). In a very real sense, justice is nothing else but the performance of this distinction. It comes into being through the administration and organization of violence-the construction of formal mechanisms through which the disjuncture of injustice is redeemed, and thereby reincorporated into the legal order (Benjamin I996).

\section{Formative Violence}

Material violence, then, generates the tension through which justice may come into being. Law's core function is to concretize this distinction, to divide the world between legitimate and illegitimate violence. This task, however, utterly founders when it encounters violence that is neither (Derrida 1992). This is a formative violence, which exceeds the politics of gain and loss. It cannot be expressed in terms of justice, but is a revolutionary and creative violence-the clearing away of space so that normative order may be written. The violence of this enclosure is never merely conceptual but instead depends on the active destruction of those who threaten to disrupt it (Schmitt 2003: 69-75). The American case offers a particularly stark picture: the continent-wide project of Indian extermination that was necessary for the formation of a new United States (Meister 20II: IO2; Gerstle 200I: 20-2I; Saxton I990: I 53). However, the problem is not uniquely American. Every legal order is built on the ashes of that which came before. We are all 'taking the place (or living on the ruins) of a vanished civilization' (Meister 2OII: 289). If it is turtles all the way down, then each turtle is birthed out of the ashes of those that came before. 
Such violence-the initial expression of law's aporia-is permanently locked into the past. It therefore exceeds any potential for remedy. It is the lingering silence of those who have been cast aside by history: the differend of justice.

The victims of this exclusion cannot be cast within the frame of 'victim' and 'perpetrator' because they no longer exist. There are no victims left, and the ruins of preexisting civilizations cannot ask for justice. At the same time, no one can be marked as perpetrator when all that remain are equally the beneficiaries of the absence in which their order has been formed. The community of justice, by the very logic of interpretive unity that binds them to the concept, cannot accept the thought of unredeemable collective communal guilt for a mass injustice. Instead, they must treat justice as the obligation to 'deplore what happened to prior inhabitants without wishing that it hadn't' (Meister 20II: 289). Certainly, this is the story told by secular modernity: right and wrong may be judged only through the lens of finitude.

However, Dworkin's brilliant unification of all interpretive models under the framework of justice clarifies that formative violence must inevitably seep back into the practices of everyday justice. Because every judgment is linked together, no judgment is free of its origin. The battle must constantly be refought. Every 'interruption', to borrow Derrida's phrase, must be brought into the fold, through violence if necessary. Such violence is justified because the alternative would be to acknowledge the existence of exclusion beyond the reach of justice. Further, this process can never be ended. In drawing the distinction between victim and perpetrator, the judge must always generate a third perspective capable of evaluation. This third standpoint necessarily lies outside the supposedly universal logic of justice. And any effort to incorporate that third will only generate a new position of judgment, against which the original concept may then be judged. This recursive impossibility for incorporation constitutes a 'meta-differend' intrinsic to the idea of discussion (Lyotard I988: 26). Each individual case of injustice thus appears available for incorporation, but the position of judgment itself always lingers as a remainder.

The goal of law, therefore, is always both an attempt to remedy injustice by incorporating it into the moral order and an effort to exterminate the lingering violence that defies incorporation. As such, even the fusing of horizons can never be truly open; it always includes an element of colonization: even if only in the characterization of that which refuses understanding to be 'unreasonable'. The cover of legitimacy thus eradicates the particularity of the victim's suffering. By fitting it into a scheme of ultimate redemption, it 'ultimately preordains the irreducible experience of suffering to a foretold redemption, meaning that [it] doesn't really allow suffering to be in its otherness but has already reduced it to sameness beforehand' (Badiou 2010: 39).

These logics of redemption serve a very specific purpose. They are not merely free-floating theories but instead are necessary and inevitable results of a system of law founded on the depoliticization of radical violence. The redemptive narrative isolates the fact of violence, modulates it, legalizes it. It treats the fact of violence as an inspiration to justification, to a logic of persuasion, whose goal is not to justify the coercive act to those upon whom it is exercised but instead is to justify 
it to those who must enact it. To organize the concept of law around this goal entails drawing together a community who may then punish those who remain exterior. The force of law is justified entirely by the fact that such outlaws could have been persuaded but chose not to be.

\section{Law's Violence: Pain and Legal Interpretation}

This problem is expressed well by Robert Cover (I986), in his excellent critique of Law's Empire. For Cover, Dworkin's approach is dangerous because it focuses on the procedure of justification and writes out the existence of the subject upon whom this law is written. The outlaw who suffers the decision is reduced to being nothing but the receptacle of legal violence. For such a person the law produces no redemption but only the bare fact of pain (Cover I986: I629). Such pain, by its nature, can never be fit into the realm of justification; indeed, pain 'destroys language itself' (Cover I986: I602).

For example, in the case of torture, even a full confession cannot confirm the legitimacy of the process. The concern here is not that torture violates a moral principle (as Dworkin might argue) and is therefore unjustifiable. Such reasoning operates within the flux of moral persuasion, and is therefore susceptible to rewriting - with both substantive arguments (exceptional need) and/or procedural ones (appropriate restraint/due process) available to offer legitimation for the act. Dworkin would likely reject such justifications as incorrect assessments of moral obligation, but this is precisely the problem. Torture cannot be folded into a rational judgment about value because the entire purpose of torture is to break the rational world apart (Cover I986: I603). Between the wielder and object of pain, no shared community is possible and 'any commonality of interpretation that may or may not be achieved is one that has its common meaning destroyed by the divergent experiences that constitute it' (Cover I986: I609). Consider the scenes at the end of 1984 , in which O'Brien tortures Winston Smith with the goal of completely realigning Smith's subjectivity. The experience of pain destroys resistance not by overwhelming the desire for freedom but rather by breaking the capacity to understand freedom as anything other than slavery (Orwell, I983, 205-9).

It may seem overly dramatic to analogize torture and the abstract workings of a legal system, but at root they employ the same logic. The law is not simply an abstract phenomenon; it 'is built only to the extent that there are commitments that place bodies on the line' (Cover I986: I605). And the important binding feature of law is not the people's willingness to affirm its principles but rather is their commitment to make themselves martyrs to its purpose, that is: to commit violence in its name. That such martyrdom has become highly formalized and abstract in the modern world does not change the underlying fact. Judicial decisions that purport to honor the hermeneutic process necessarily overlook the institutional structure of those judgments; they miss the 'pre-legal' feature of legal interpretation (Goorden 20I2). The law is a political object, one held together by the collective administration of violence in the name of (a particular concept of) 
justice (Dallmayr I992: I7-I 8 ). And the interpretive community of law is always a finite body built against its excluded remainders.

In this way, the formative violence of law is manifested in every decision. Law's structural exclusion is not simply the abstract loss of faded civilizations; it is instead carried forward through the act of interpretation and made present in every new decision. As a permanent disjuncture in the concept of justice, formative violence ensures the continual reenactment of daily exclusion. The judgment is made to distribute pain, but that pain cannot be conceptually fit into the normative order of justice. It is neither just nor unjust. It simply is. And behind the veil of interpretation lie only material bodies that suffer, bereft of law's redemption.

Cover's analysis of the world-destroying fact of pain demonstrates the very real consequences. A brick wall of implicit violence blocks the persuasive appeal of law from obtaining universality. In the body of the accused criminal, its terminal breakdown is made clear. Recall Dworkin's argument that moral reason is founded on the doctrine of responsibility: that one must treat others as objectively important in order to make any moral claim. The dark underside of this premise is made clear in an innocent-seeming passage about mutual recognition. Because respect is mutual, he argues, moral agents must respect others 'only so far as they accept the burden of responsibility . . . because only then do they really accept that equal importance' (Dworkin 20II: II3). The criminal facing the violence of incarceration, or the exterminated ghosts of the past, will find little comfort in this sense of mutual respect.

\section{Justice and the Limits of Reason}

The desperate need of every political philosophy is to translate unlimited (and thus incomprehensible) violence into 'injustice'. Once so rendered, such exclusion can be redeemed by isolating its pain as past and drawing its injunction for reparation into the present. However, such redemption is always incomplete, founded as it is on the erasure of that violence which cannot be transmuted in this way.

To illustrate this process, I have explored three seemingly distinct interpretive modes. Using the framework set up in Justice for Hedgehogs, the apparent differences collapsed into a larger unity: the goal of redemption. Each one, in a distinct way, reflects the underlying logic of life in an inter-messianic, secular age. They arise from the need to cope with irresolvable doubt. That coping takes the form of second chances. Hope is never extinguished but instead comes to life through the continual process of redeeming evil. What has become clear is that this approach founders on its conceptual limits. The interpreting subject lives within a moral universe but cannot grasp the formative violence that is enacted by a moral universe (its differend). And this interpretive gap is occluded by the concept of justice.

Dworkin attempts to resolve the tempestuous battle that has defined modern politics-legality versus legitimacy, morality versus politics. He observes a perpetual indeterminacy and refuses to collapse the contradiction by choosing a side. Armed with a deep faith that goodness may be found within the scope of 
human reason, he reaches into Schrödinger's box and draws out a hedgehog. However, this very faith is itself the perfect realization of reason's limit. By sanding away all the rough edges from the normative case for justice and expressing it in all-encompassing terms, Dworkin takes us onto 'slippery ice where there is no friction and so in a certain sense the conditions are ideal, but also, just because of that, we are unable to walk. We want to walk: so we need friction. Back to the rough ground!' (Wittgenstein I968: $\$$ I07). That is: by treating justice as a subject of reason, he removes it as far as possible from the active practice of law. If justice is simply a matter of persuasion, then the enactment of its precepts becomes relegated to mere enforcement. What is lost here is the way in which such enforcement, the delineation of a line between us and them, is the essence of judgment itself. In this, law's violence is fully externalized; it becomes the differend of law.

Justice for Hedgehogs, by seeking completely to eliminate the exclusions of politics that stem from a relativistic worldview, circles entirely around to meet itself on the other side. Its terminal point of enclosure is found by reversing its most basic maxim. If relativism is always a moral concept, then so is the opposite true: every moral concept is ultimately a form of relativism. And the more that justice is differentiated from the world-breaking fact of violence, the closer it comes to enacting precisely the violence it seeks to end.

CHARLES OLNEY (6)

UNIVERSITY OF TEXAS AT RIO GRANDE VALLEY charles.olney@utrgv.edu

\section{References}

Badiou, Alain. (2010) Five Lessons on Wagner. Translated by Susan Spitzer. London: Verso.

Badiou, Alain. (20II) Wittgenstein's Antiphilosophy. Translated by Bruno Bosteels. New York: Verso.

Balkin, Jack. (20I I) Constitutional Redemption: Political Faith in in an Unjust World. Cambridge, MA: Harvard University Press.

Barrow, John. (2005) The Infinite Book: A Short Guide to the Boundless, Timeless and Endless. New York: Pantheon Books.

Benjamin, Walter. (I996) 'Critique of Violence'. In Marcus Bullock and Michael Jennings (eds.), Selected Writings, Vol. I, I913-I926 (Cambridge, MA: Harvard University Press), 236-52.

Berlin, Isaiah. (1953) The Hedgehog and the Fox: An Essay on Tolstoy's View of History. London: Weidenfeld and Nicolson.

Cornell, Drucilla, and Nick Friedman. (2010) 'The Significance of Dworkin's Non-Positivist Jurisprudence for Law in the Post-Colony'. Malawi Law Journal, 4, I-94.

Cover, Robert (I986) 'Violence and the Word'. Yale Law Journal, 95, I60I-29.

Dallmayr, Fred. (1992) 'Hermeneutics and the Rule of Law'. In Gregory Leyh (ed.), Legal Hermeneutics: History, Theory, and Practice (Berkeley: University of California Press), 3-22.

Derrida, Jacques. (1978) Writing and Difference. Translated by Alan Bass. Chicago: University of Chicago Press.

Derrida, Jacques. (1989) 'Three Questions to Hans-Georg Gadamer'. In Diane Michelfelder and Richard Palmer (eds.), Dialogue and Deconstruction: The Gadamer-Derrida Encounter (Albany: State University of New York Press), 52-53. 
Derrida, Jacques. (I992) 'Force of Law: The Mystical "Foundation of Authority". In Drucilla Cornell, Michael Rosenfeld, and David Carlson (eds.), Deconstruction and the Possibility of Justice (New York: Routledge), 3-67.

Donato, James. (I988) 'Dworkin and Subjectivity in Legal Interpretation'. Stanford Law Review, 40, I 5 I7-54I.

Dworkin, Ronald. (1986) Law's Empire. Cambridge, MA: Harvard University Press.

Dworkin, Ronald. (2OII) Justice for Hedgehogs. Cambridge, MA: Harvard University Press.

Fleming, James. (I997) 'Fidelity to Our Imperfect Constitution'. Fordham Law Review, 65, I33555 .

Gadamer, Hans Georg. (I989) 'Reply to Jacques Derrida'. In Diane Michelfelder and Richard Palmer (eds.), Dialogue and Deconstruction: The Gadamer-Derrida Encounter (Albany: State University of New York Press), 55-57.

Gadamer, Hans-Georg. (2004) Truth and Method. New York: Continuum.

Gerstle, Gary. (200I) American Crucible: Race and Nation in the 2oth Century. Princeton, NJ: Princeton University Press.

Goorden, Dean. (20I2) 'Dworkin and the Phenomenology of the "Pre-Legal"?'. Ratio Juris, 25, 393-408.

Habermas, Jürgen. (I990) 'The Hermeneutic Claim to Universality'. In Gayle Ormiston and Alan Schrift (eds.), The Hermeneutic Tradition: From Ast to Ricouer (Albany: State University of New York Press), 245-72.

Hart, H. L. A. (1994) The Concept of Law. Oxford: Clarendon Press.

How, Alan. (1995) The Habermas-Gadamer Debate and the Nature of the Social: Back to Bedrock. Brookfield: Avebury.

Hutchinson, Allan. (1987) 'Indiana Dworkin and Law's Empire'. Yale Law Journal, 96, 637-65.

Locke, John. (2008) Second Treatise of Government. In Peter Laslett (ed.), Two Treatises of Government (Cambridge: Cambridge University Press), 265-428.

Lyotard, Jean-François. (1988) The Differend: Phrases in Dispute. Translated by Georges Van Den Abbeele. Minneapolis: University of Minnesota Press.

Meister, Robert. (20I I) After Evil. New York: Columbia University Press.

Nietzsche, Friedrich. (1967) On the Genealogy of Morals. Translated by Walter Kaufmann and R. J. Hollingdale. New York: Random House.

O'Neill, Onora. (I997) 'Political Liberalism and Public Reason: A Critical Notice of John Rawls, Political Liberalism'. Philosophical Review, I06, 4I I-28.

Orwell, George. (1983) I984. New York: Signet Classic.

Přibáň, Jiří. (2006) 'The Time of Constitution-Making: On the Differentiation of the Legal, Political and Moral Systems and Temporality of Constitutional Symbolism'. Ratio Juris, I9, 456-78.

Rawls, John. (2005) Political Liberalism. New York: Columbia University Press.

Saxton, Alexander. (1990) The Rise and Fall of the White Republic: Class Politics and Mass Culture in Nineteenth Century America. London: Verso.

Schmitt, Carl. (I985) Political Theology: Four Chapters on the Concept of Sovereignty. Translated by George Schwab. Cambridge, MA: Massachusetts Institute of Technology Press.

Schmitt, Carl. (2003) The Nomos of the Earth in the International Law of the Jus Publicum Europaeum. Translated by G. L. Ulmen. New York: Telos Press.

Shapcott, Richard. (200I) Justice, Community and Dialogue in International Relations. Cambridge: Cambridge University Press.

Wittgenstein, Ludwig. (I968) Philosophical Investigations. Translated by G. E. M. Anscombe. New York: MacMillan. 